\title{
Effect of Drip Irrigation on Yield, Evapotranspiration and Water Use Efficiency of Sweet Basil (Ocimum basilicum L.)
}

\author{
Borivoj Pejić1 · Dušan Adamović $\cdot$ Livija Maksimović $^{2}$ Ksenija Mačkić ${ }^{1 *}$ \\ ${ }^{1}$ University of Novi Sad, Faculty of Agriculture, Trg Dositeja Obradovića 8, 21000 Novi Sad, Serbia \\ Institute of Field and Vegetable Crops, Maksima Gorkog 30, 21000 Novi Sad, Serbia
}

\begin{abstract}
Summary: The experiments showing the effect of drip irrigation on yield, evapotranspiration and water productivity of sweet basil (Ocimum basilicum L.) were conducted at the experimental field of the Alternative Crops Department, Institute of Field and Vegetable Crops, Novi Sad. Irrigation was scheduled on the basis of the water balance method. Daily evapotranspiration $\left(\mathrm{ET}_{\mathrm{d}}\right)$ was computed from the reference evapotranspiration $\left(E T_{\mathrm{o}}\right)$ and crop coefficient $(\mathrm{kc})$ in May, June, July and August of 0.5, 0.6, 1.1 and 1.0, respectively. ET $\mathrm{T}_{\mathrm{o}}$ was calculated using Hargreaves equation. The irrigation depth was restricted to the soil depth of $0.3 \mathrm{~m}$. In other words, irrigation started when readily available water in the soil layer of $0.3 \mathrm{~m}$ was completely depleted by plants. The irrigation rate was $30 \mathrm{~mm}\left(30 \mathrm{l} \mathrm{m}^{-2}\right)$ while the amount of water added by irrigation during the season was $140 \mathrm{~mm}$. Basil sensitivity to water stress was determined using a yield response factor $\left(\mathrm{K}_{\mathrm{y}}\right)$. According to the results, the yield of fresh herb of basil under irrigation $\left(32.015 \mathrm{t} \mathrm{ha}^{-1}\right)$ was higher by $9 \%$ compared to non-irrigated, control variant $\left(29.364 \mathrm{t} \mathrm{ha}^{-1}\right)$. Worthy of note, basil essential oil yield was significantly affected by irrigation $(35.329 / 28.766$ $\left.\mathrm{kg} \mathrm{ha}^{-1}\right)$. The content of essential oil was significantly higher in irrigated $\left(6.45 \mathrm{~g} \mathrm{~kg}^{-1}\right)$ than in non-irrigated variant $\left(5.33 \mathrm{~g} \mathrm{~kg}^{-1}\right)$ in the first harvest, while no significant difference between irrigated and non-irrigated variants was obtained in the second harvest (6.83 and $6.62 \mathrm{~g} \mathrm{~kg}^{-1}$, respectively). Water used on evapotranspiration in irrigation conditions $\left(\mathrm{ET}_{\mathrm{m}}\right)$ was $431 \mathrm{~mm}$ and $270 \mathrm{~mm}$ in non-irrigated, control variant $\left(\mathrm{ET}_{\mathrm{a}}\right)$. The values of irrigation water use efficiency $\left(\mathrm{I}_{\mathrm{wue}}\right)$ and evapotranspiration water use efficiency $\left(\mathrm{ET}_{\text {wue }}\right.$ ) were $1.89 \mathrm{~kg} \mathrm{~m}^{-3}$ and $1.65 \mathrm{~kg} \mathrm{~m}^{-3}$ respectively. $\mathrm{K}_{\mathrm{y}}$ value $(0.22)$ exhibits all essential characteristics of climate conditions of 2016 rainy year. These preliminary results could be used as a good platform for basil growers in the region, in terms to optimize the use of irrigation water.

Key words: basil, evapotranspiration, irrigation, Ocimum basilicum L., water use efficiency, yield
\end{abstract}

\section{Introduction}

Basil (Ocimum basilicum L.) is a widely grown aromatic crop cultivated either for the production of essential oil, dry leaves for the market, or as an ornamental plant (Simon et al., 1990). Nearly 60 species of basil are known throughout the world and cultivated in France, Egypt, Hungary, Indonesia, Marocco, the United States, Russia, Greece and Israel (Srivastava, 1980; Kišgeci \& Adamović, 1994; Adamović, 2012 a, b). The useful parts of the basil are its leaves and seeds. Basil is used in food industry as a flavoring agent and also in perfumery and medical industries (Simon et al., 1990). In northern parts of Serbia (the Vojvodina region), the area occupied by medicinal plants is rather small in comparison to other crops. In last decade, organized production of these plant species was on 1,300-2,400 ha. Many researchers, in different climate and soil conditions, have evaluated the positive effect of irrigation on yield and quality characteristics of basil (Singh, 2002; Yassen et al., 2003; Khalid, 2006; Moeini Alishah et al., 2006; Jevđović et al., 2009; Ekren et al., 2012). The effect of irrigation on herb and essential oil

Corresponding author:

ksenija@polj.uns.ac.rs yield of basil has not been studied enough in the Vojvodina region.

Sensitivity of basil plants to water stress and irrigation could be determined by using the yield response factor $\left(\mathrm{K}_{\mathrm{y}}\right)$ and water use efficiency (WUE). $\mathrm{K}_{\mathrm{y}}$ represents the relationship between a relative yield decrease $(1-\mathrm{Ya} / \mathrm{Ym})$ and a relative evaporation deficit (1-ET $\mathrm{T}_{\mathrm{a}} / \mathrm{ET}_{\mathrm{m}}$ ) (Doorenbos \& Kassam, 1979). Defined as the increase in yield per unit of irrigation water applied, irrigation water use efficiency $\left(I_{\text {wue }}\right.$ ) can be calculated if the amounts of water given by irrigation and actual yield increase from irrigation are known (Howell, 2001). $I_{\text {wue }}$ provides the most realistic assessment of the irrigation effectiveness (Pejić et al., 2011; Pejić et al., 2014). ET wue $_{\text {we }}$ coefficient clearly defines whether the growing period is favorable for plant production or not, mostly depending on precipitation amount and distribution. Furthermore, these parameters precisely assess the applied management practices in relation to the obtained yields of growing plants (Pejić et al., 2011).

The aim of this research was to get information of how the plants of basil react to irrigation and water stress under Vojvodina climate conditions, including evapotranspiration. Obtained results could be used as a good platform for basil growers in the region to optimize the use of irrigation water. 


\section{Material and Method}

The experiment was conducted at experimental field

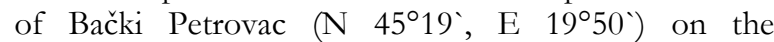
calcareous chernozem soil on the loess terrace, in 2016. In the period 1964 - 2015, the annual mean air temperature, precipitation and relative humidity were $11.2^{\circ} \mathrm{C}, 598.7 \mathrm{~mm}$ and $76 \%$, respectively. According to the Hargreaves climate classification system, the study area is classified as arid during summers (June - August) (Bošnjak, 2001). In the growing season (May-August), the mean temperature and total rainfall were $21.5^{\circ} \mathrm{C}$ and $253 \mathrm{~mm}$, respectively. The irrigated (well-watered) variant was established in completely randomized design with three replications and adapted to technical specifications of the drip irrigation system. The trial also included the non-irrigated (rainfed) control variant. The preceding crop was corn. Soil bedding included soil ploughing at $0.3 \mathrm{~m}$ depth in autumn. The seeds were sown with a hand-held seeder on May 9 while sprouting was observed on May 17. The size of the experimental plot was $21 \mathrm{~m}^{2}$. Plot was made up of three rows (at 0.7 $\mathrm{m}$ spacing) of $10 \mathrm{~m}$ in length each. The plants were harvested in full bloom on July 20 and August 30 by hand, $10 \mathrm{~cm}$ above the surface and immediately weighed for the obtained fresh plot yields. The plot yield was converted to a yield in tons per hectare. Harvested biomass was dried in a solar dryer. Essential oil content was determined by standard procedure (Ph. Jug. V, 2000). Essential oil yield was calculated and expressed in kg ha-1.

The plants were irrigated with a lateral row per plant row $(0.7 \mathrm{~m})$ with drippers spaced every $0.1 \mathrm{~m}$. The drippers had an average flow of $1.41 \mathrm{~h}^{-1}$ under a pressure of $70 \mathrm{kPa}$. Irrigation was scheduled on the basis of water balance method using reference evapotranspiration $\left(\mathrm{ET}_{\mathrm{o}}\right)$ and crop coefficients $(\mathrm{kc}) . \mathrm{ET}_{\mathrm{o}}$ was calculated by Hargreaves equation (Hargreaves \& Samani, 1985).

$$
\mathrm{ET}_{\mathrm{o}}=0.0023\left(\mathrm{~T}_{\mathrm{m}}+17.8\right)\left(\sqrt{\mathrm{T}_{\max }-\mathrm{T}_{\min }}\right) \mathrm{R}_{\mathrm{a}}
$$

$\mathrm{ET}_{\mathrm{o}}$ - reference evapotranspiration $\left(\mathrm{mm} \mathrm{day}{ }^{-1}\right), \mathrm{T}_{\mathrm{m}}$ the average daily air temperature $\left({ }^{0} \mathrm{C}\right), \mathrm{T}_{\max }-$ the maximum daily temperature $\left({ }^{0} \mathrm{C}\right), \mathrm{T}_{\min }-$ the minimum daily temperature $\left({ }^{0} \mathrm{C}\right), \mathrm{R}_{\mathrm{a}}$ - the extraterrestrial radiation $\left(\mathrm{mm} \mathrm{d}^{-1}\right)$.

Daily evapotranspiration $\left(\mathrm{ET}_{\mathrm{d}}\right)$ was computed using the reference evapotranspiration $\left(\mathrm{ET}_{\mathrm{o}}\right)$ and crop coefficient $(\mathrm{kc})$ of $0.5,0.6,1.1$ and 1.0 for May, June, July and August, respectively. Irrigation started when readily available water in the soil layer of $0.3 \mathrm{~m}$ was completely absorbed by plants. The irrigation rate was $30 \mathrm{~mm}\left(30 \mathrm{l} \mathrm{m}^{-2}\right)$ (Figure 1). The volume of irrigation water was measured by flow meters installed in the hose nozzle used for irrigation.

The evaluation of water related stress conditions that affected basil yield due to the soil water deficit during the plant growing season was done using the yield response factor $\left(K_{y}\right)$.

\section{Yield response factor}

The yield response factor $\left(K_{y}\right)$ for total growing season was determined using the Steward's model (Doorenbos \& Kassam, 1979) as follows:

$$
\left(1-\frac{\mathrm{Y}_{\mathrm{a}}}{\mathrm{Y}_{\mathrm{m}}}\right)=\mathrm{K}_{\mathrm{y}}\left(1-\frac{\mathrm{ET}_{\mathrm{a}}}{E \mathrm{~T}_{\mathrm{m}}}\right)
$$

Where: $Y_{a}=$ the actual harvested yield (nonirrigated, $\mathrm{kg} \mathrm{ha} \mathrm{h}^{-1}$, $\mathrm{Y}_{\mathrm{m}}=$ the maximum harvested yield (under irrigation, non-limiting conditions, $\mathrm{kg} \mathrm{ha}^{-1}$ ), $\mathrm{K}_{\mathrm{y}}=$ the yield response factor, $\mathrm{ET}_{\mathrm{a}}=$ the actual evapotranspiration $(\mathrm{mm})$ corresponding to $\mathrm{Y}_{\mathrm{a}}, \mathrm{ET}_{\mathrm{m}}=$ the maximum evapotranspiration $(\mathrm{mm})$ corresponding to $\mathrm{Y}_{\mathrm{m}},\left(1-\mathrm{ET}_{\mathrm{a}} / \mathrm{ET}_{\mathrm{m}}\right)=$ the relative evapotranspiration deficit, and $\left(1-Y_{a} / Y_{m}\right)=$ the relative yield decrease.

\section{Water productivity}

Irrigation water use efficiency $\left(\mathrm{I}_{\text {wue }}, \mathrm{kg} \mathrm{m}^{-3}\right)$ and evapotranspiration water use efficiency $\left(\mathrm{ET}_{\text {wue }}, \mathrm{kg} \mathrm{m}^{-3}\right)$ were estimated as Bos $(1980,1985)$.

$$
\begin{aligned}
\mathrm{I}_{\text {wue }} & =\frac{\mathrm{Y}_{\mathrm{m}}-\mathrm{Y}_{\mathrm{a}}}{\mathrm{I}} \\
\mathrm{ET}_{\text {wue }} & =\frac{\mathrm{Y}_{\mathrm{m}}-\mathrm{Y}_{\mathrm{a}}}{E \mathrm{~T}_{\mathrm{m}}-\mathrm{ET}}
\end{aligned}
$$

Where: $\mathrm{I}=$ the amount of irrigation water applied $\left(\mathrm{m}^{3} \mathrm{ha}^{-1}\right)$

All recommended agronomic practices were applied for cultivation and plant protection at the experimental site. Precipitation and air temperature data were obtained from Meteorological Station located at Bački Petrovac experimental field. Data reported for yield of fresh plant material, essential oil content and essential oil yield of sweet basil were assessed by analyses of variance (ANOVA) and Fisher's LSD test was used to identify significant differences at the $\mathrm{p}<0.05$ levels between the mean values. Different letters indicate significant differences between values.

\section{Results and Discussion}

The challenges imposed by arid summer conditions to basil growers may be lessen by irrigated farming offering potential to ensure maximal yield and oil quality. On the other hand, in the variable climate of Vojvodina no long-term rainfall prediction is possible, giving rise to overlapping of irrigation and heavy rains. In such a case nutrients are taken away from shallow to deeper soil layers, confirming a supplementary character of irrigation in this region (Pejić et al., 2014). Pejić et al. $(2009,2011)$ quoted that in rainy years the impact of 
irrigation on yield of growing plants may be negligible to missing. In the vegetation season 2016 rainfall amounted $253 \mathrm{~mm}$ while the amount of water added by irrigation was $140 \mathrm{~mm}$ (Figure 1, Table 2). In the period from emergence to the first harvest precipitation amounted $182 \mathrm{~mm}$ (Figure 1). In that period irrigation was performed three times with total water of $80 \mathrm{~mm}$ (Figure 1). First irrigation with $30 \mathrm{~mm}$ on June 27 was followed by $48.1 \mathrm{~mm}$ of rain the next day. Second irrigation was done on July 6 with $30 \mathrm{~mm}$ of water. After third irrigation on July 14 with irrigation rate of $20 \mathrm{~mm}, 62 \mathrm{~mm}$ of heavy rain occurred two days later (Figure 1).
Amount and uneven distribution of rainfall is the main reason why there were no statistical differences in the yield of fresh basil plant material between irrigated and non-irrigated conditions, both between first $\left(18.587 / 17.005 \mathrm{t} \mathrm{ha}^{-1}\right)$ and second harvest $\left(13.428 / 12.539 \mathrm{t} \mathrm{ha}^{-1}\right)$ and for the entire growing season (32.015/29.364 t ha-1 (Table 2, Figure 1). The yield in irrigation conditions was $9.3 \%, 7.1 \%$ and $9.0 \%$ higher, as compared with the control, for the first and second harvest and entire growing season, respectively. The results are in agreement with many studies conducted in a wide range of environments which confirm that

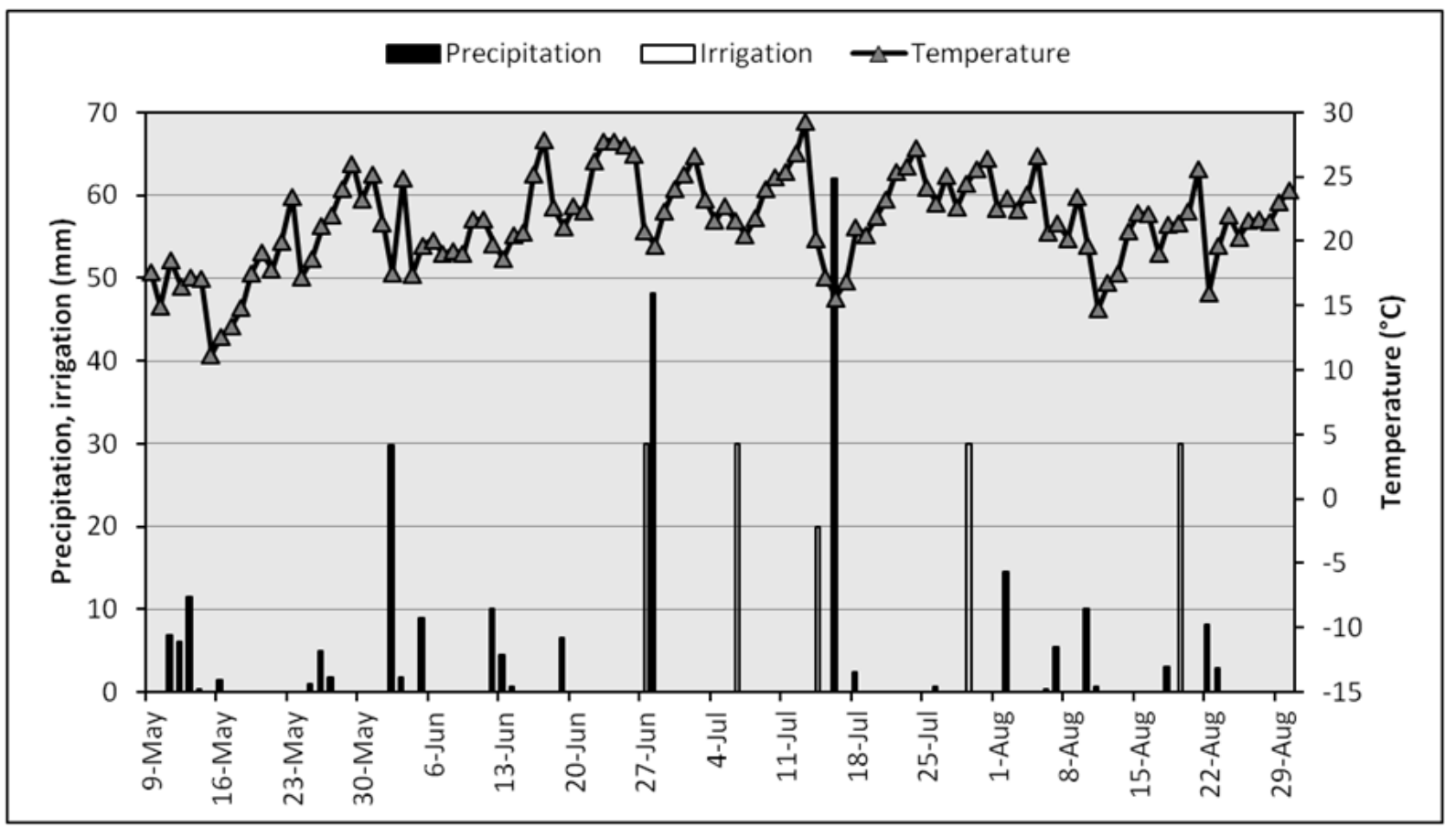

Figure 1. Irrigation schedules, irrigation water applied and meteorological data for the experimental year

Table 1. Water balance of sweet basil

\begin{tabular}{lcccc}
\hline \multirow{2}{*}{ Elements } & $\begin{array}{c}\text { Sowing } \\
\text { emergence }\end{array}$ & $\begin{array}{c}\text { Emergence } \\
1^{\text {st }} \text { harvest }\end{array}$ & $\begin{array}{c}1^{\text {st }} \text { harvest } \\
2^{\text {nd }} \text { harvest }\end{array}$ & Total/Average \\
\cline { 2 - 5 } & $09 / 05-17 / 05$ & $18 / 05-20 / 07$ & $21 / 07-30 / 08$ & $09 / 05-30 / 08$ \\
\hline $\mathrm{ET}_{\mathrm{o}}(\mathrm{mm})$ & 45.8 & 310.2 & 186.5 & 542.5 \\
$\mathrm{ET}_{\mathrm{m}}(\mathrm{mm})$ & 13 & 225 & 193 & 431 \\
Water used on $\mathrm{ET}_{\mathrm{m}}(\%)$ & 3 & 52.2 & 44.8 & 100 \\
Duration (days) & 9 & 64 & 41 & 114 \\
$\mathrm{ET}(\mathrm{mm})$ & 1.4 & 3.5 & 4.7 & 3.2 \\
$\mathrm{P}(\mathrm{mm})$ & 26 & 182 & 45 & 253 \\
$\Delta$ & 0 & -13 & 0 & - \\
$\mathrm{r}(\mathrm{mm})$ & 30 & 30 & 0 & - \\
$\mathrm{ET} T_{\mathrm{a}}(\mathrm{mm})$ & 13 & 212 & 45 & 270 \\
$\mathrm{~d}(\mathrm{~mm})$ & 0 & 13 & 148 & 161 \\
$\mathrm{~s}(\mathrm{~mm})$ & 13 & 0 & 0 & 13 \\
\hline
\end{tabular}

$\mathrm{ET}_{\mathrm{o}}$ - the reference evapotranspiration $(\mathrm{mm}), \mathrm{ET}_{\mathrm{m}}$ - the maximum evapotranspiration-irrigated (mm), ET - the actual evapotranspiration rainfed $(\mathrm{mm}), \mathrm{ET}_{\mathrm{d}}$ - the daily maximum evapotranspiration-irrigated $(\mathrm{mm}), \mathrm{P}-$ monthly rainfall sum $(\mathrm{mm}), \Delta \pm-$ inflow and outflow of water into the soil reserve $(\mathrm{r}), \mathrm{d}$ - deficit of readily available water and $\mathrm{s}-$ surplus, percolated water 


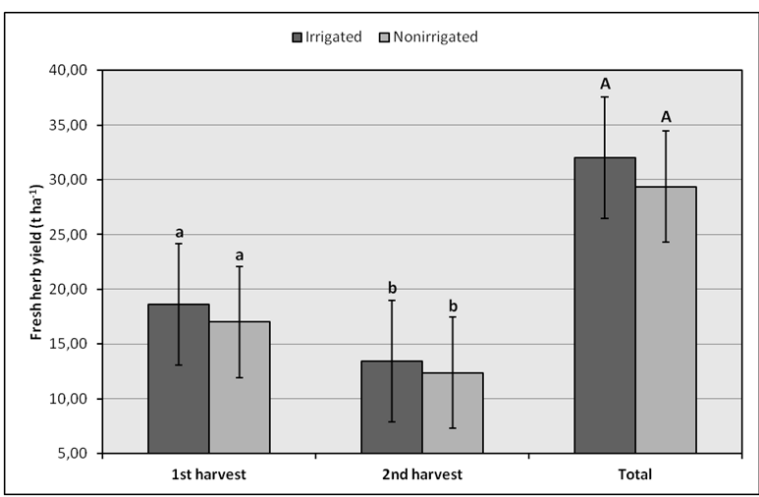

Figure 2. Fresh herb yield $\left(\mathrm{t} \mathrm{ha}^{-1}\right)$ of sweet basil under irrigated and non-irrigated conditions

irrigation can positively affect the yield increase of fresh herb of basil (Singh, 2002; Khalid, 2006; Biesiada \& Kus, 2010; Ekren et al., 2012). Favorable years for plant production in terms of amount and distribution of precipitations are rare in the region. Drought is a regular phenomenon. It occurs almost every year, occasionally causing catastrophic reductions in yield of growing plants (Bošnjak, 2001). A high yield of fresh herb, either in irrigation or in rainfed conditions confirms that soil and climate conditions might be suitable for basil production in Vojvodina. In a mild Mediterranean climate of Turkey, Ekren et al. (2012) reported the yield of fresh herb of $22.694 \mathrm{t} \mathrm{ha}^{-1}$.

Water used on evapotranspiration in irrigation conditions $\left(E \mathrm{~T}_{\mathrm{m}}\right)$ was $431 \mathrm{~mm}$ while $270 \mathrm{~mm}$ in nonirrigated control ( $\left(\mathrm{ET}_{\mathrm{a}}\right)$ (Table 1 and 2). The highest evapotranspiration rate in irrigation conditions $\left(\mathrm{ET}_{\mathrm{m}}\right)$ was calculated for the first harvest and amounted to 225 $\mathrm{mm}$, or $52.2 \%$ of total water used during entire growing season (Table 1). The highest average value of $4.7 \mathrm{~mm}$ of daily water used on evapotranspiration $\left(E T_{d}\right)$ was detected in the second harvest while the average value for the entire growing season was $3.2 \mathrm{~mm}$ (Table 1). Maximum daily evapotranspiration value of $7.6 \mathrm{~mm}$ was detected on July 11 (Figure 3). Obtained results of maximum basil ET are in accordance with values of 8.5 $\mathrm{mm}$ recorded by Ghamarnia et al. (2015) in semi-arid conditions of western Iran. Similar value of basil $\mathrm{ET}_{\mathrm{m}}$ (401.4 mm) was reported by Singh (2002) for semi-arid tropical climate of India.

The best method to describe the role that irrigation has in water use efficiency (WUE) in irrigated farming is by expressions given by Bos $(1980,1985)$. Many researchers have evaluated water use efficiency in different ways

Table 2. Yield response factor and water productivity of sweet basil

\begin{tabular}{cccccccccc}
\hline $\mathrm{ET}_{\mathrm{m}}$ & $\mathrm{ET}_{\mathrm{a}}$ & $\mathrm{Y}_{\mathrm{m}}$ & $\mathrm{Y}_{\mathrm{a}}$ & $1-\mathrm{ET}_{\mathrm{a}} / \mathrm{ET}_{\mathrm{m}}$ & $1-\mathrm{Y}_{\mathrm{a}} / \mathrm{Y}_{\mathrm{m}}$ & $\mathrm{K}_{\mathrm{y}}$ & $\mathrm{I}$ & $\mathrm{I}_{\text {wue }}$ & $\mathrm{ET}_{\text {wue }}$ \\
\hline 431 & 270 & 32.015 & 29.364 & 0.37 & 0.08 & 0.22 & 140 & 1.89 & 1.65 \\
\hline
\end{tabular}

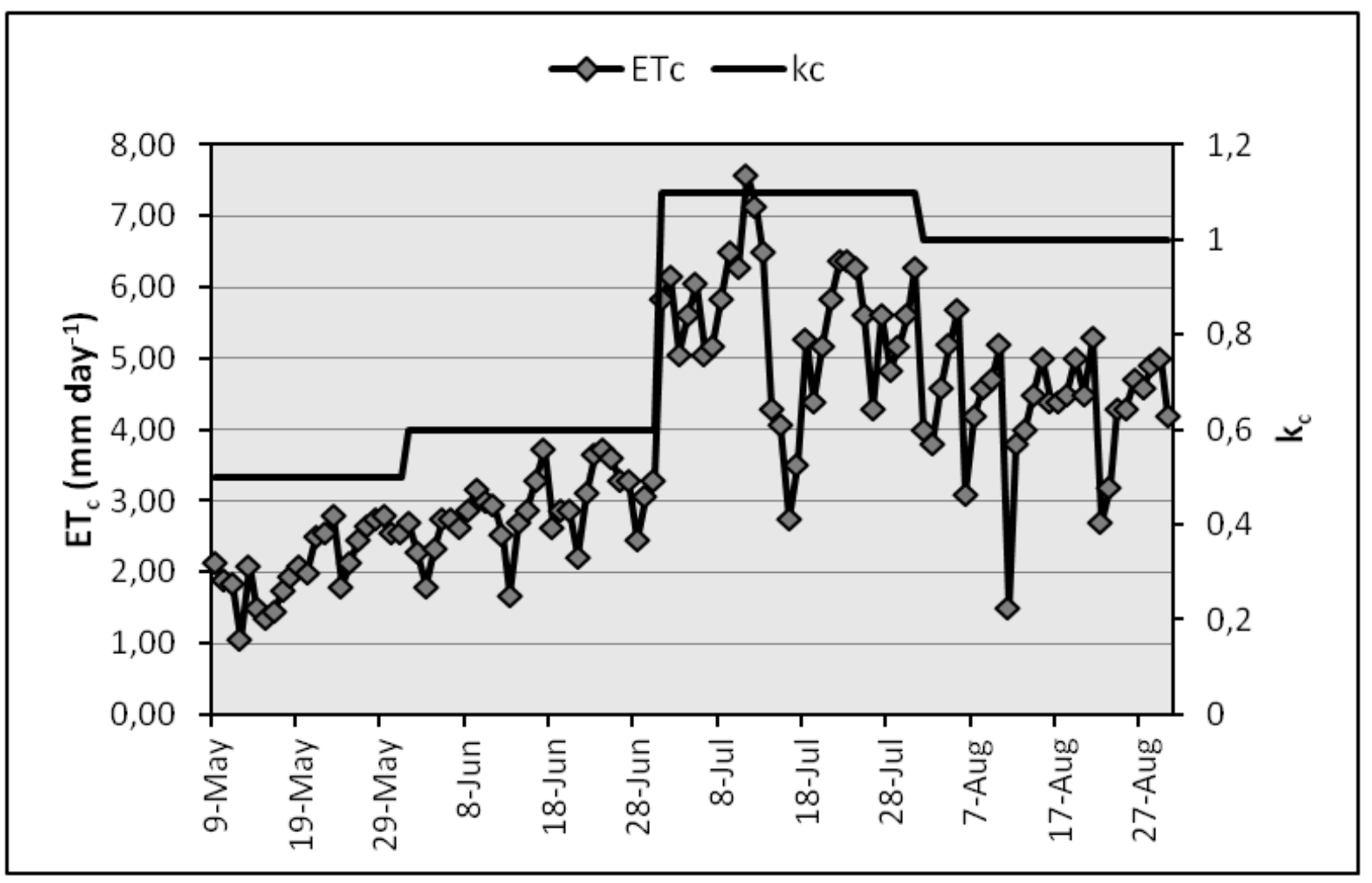

Figure 3. Daily evapotranspiration and crop coefficient of sweet basil 


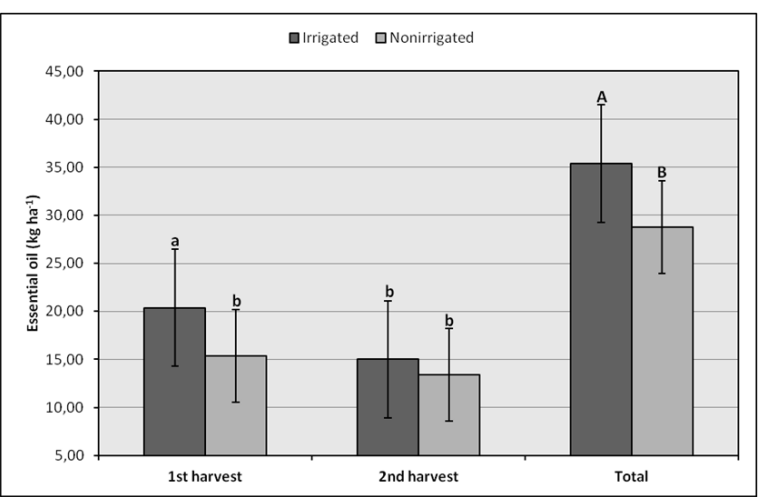

Figure 4. Yield of essential oil $\left(\mathrm{kg} \mathrm{ha}^{-1}\right)$ of sweet basil under irrigated and non-irrigated conditions for the first and second harvest

(Howell, 2001; Payero et al., 2006). Consequently, care should be taken when comparing WUE values. Irrigation water use efficiency $\left(I_{\text {wue }}\right)$ and evapotranspiration water use efficiency $\left(\mathrm{ET}_{\mathrm{wue}}\right)$ determined in the period of investigation were $1.89 \mathrm{~kg} \mathrm{~m}^{-3}$ and $1.65 \mathrm{~kg} \mathrm{~m}^{-3}$, respectively (Table 2).

The yield response to water deficit of different crops is of major importance in production planning. A larger $\mathrm{K}_{\mathrm{y}}$ value indicates greater yield losses due to water deficit. $K_{y}$ value of 0.22 (Table 2) is in agreement with climate conditions of the rainy year 2016. Cakir (2004) reported that values of $K_{y}$ for a given crop and locality varied from year to year even at the same location. Pejić et al. (2011, 2009) cited low values of $K_{y}$ for corn (0.21-0.46) and sunflower (0.070-0.029) in supplementary irrigation in temperate climate of the Vojvodina region that is in agreement with above reference. The same author (Cakir, 2004) also reported the higest $\mathrm{K}_{\mathrm{y}}$ value of corn (1.36) in the season which experienced severe drought whereas much lower value $(0.81)$ for the rainy year.

Basil essential oil content in dry herb was significantly affected by irrigation in the first harvest $\left(6.45 / 5.33 \mathrm{~g} \mathrm{~kg}^{-1}\right)$. The difference between irrigated $\left(6.83 \mathrm{~g} \mathrm{~kg}^{-1}\right)$ and non-irrigated $\left(6.62 \mathrm{~g} \mathrm{~kg}^{-1}\right)$ variants was not significant in the second harvest (Table 3). Ekren et al. (2012) reported statistically the highest essential oil content of basil in variant of $50 \%$ of field capacity $(1.15 \%)$ compared with $75(0.91 \%)$ and $125 \%$ (0.88\%).

Essential oil yield $\left(\mathrm{kg} \mathrm{ha}^{-1}\right)$ of basil was significantly influenced by irrigation (Figure 4). In the first harvest, the obtained oil yield differences were statistically significant $\left(20.380 / 15.394 \mathrm{~kg} \mathrm{ha}{ }^{-1}\right)$. The differences between irrigated and non-irrigated variant of the second harvest were recorded but not yet statistically significant (15.012/13.372 kg ha-1), (Figure 4). Total oil yield (for full vegetative season), in irrigated $(35.329 \mathrm{~kg}$ $\left.\mathrm{ha}^{-1}\right)$ and non-irrigated variant $\left(28.766 \mathrm{~kg} \mathrm{ha}^{-1}\right)$ indicates that climate and soil conditions of Vojvodina region may be favorable for sweet basil production. The presented results are in agreement with those of Singh (2002) who reported the highest herb and oil yields in variant of 0.75 cumulative pan evaporation $\left(78.81 \mathrm{~kg} \mathrm{ha}^{-}\right.$
Table 3. Content of essential oil ( $\mathrm{g} \mathrm{kg}^{-1}$ of dry herb) of sweet basil under irrigated and non-irrigated conditions for the first and second harvest

\begin{tabular}{lcc}
\hline Variant & $1^{\text {st }}$ harvest & $2^{\text {nd }}$ harvest \\
\hline Irrigated & $6.45^{\mathrm{a}}$ & $6.83^{\mathrm{a}}$ \\
Non-irrigated & $5.33^{\mathrm{b}}$ & $6.62^{\mathrm{a}}$ \\
\hline Values with different letters are statistically significant $(\mathrm{P}<0.05)$
\end{tabular}

Values with different letters are statistically significant $(\mathrm{P} \leq 0.05)$

1) compared with $0.50\left(65.45 \mathrm{~kg} \mathrm{ha}^{-1}\right)$ and $0.25(62.48 \mathrm{~kg}$ $\left.\mathrm{ha}^{-1}\right)$, as the result of favorable soil moisture conditions maintained throughout the crop growing period. Under the conditions of higher moisture supply, the crop covers the ground faster therefore increasing the photosynthetic efficiency to achieve maximum utilization of solar radiation resulting in significant increase in herb yield and oil yield (Singh, 2002).

\section{Conclusions}

In the study, the yield of sweet basil fresh herb was higher in irrigated variant than in non-irrigated variant by $9 \%$ but this difference was not statistically significant. On the contrary, significant difference in essential oil content in the first harvest, between irrigated variant and the control was recorded. Essential oil yield was significantly affected by irrigation.

Water used for evapotranspiration in irrigation conditions $\left(\mathrm{ET}_{\mathrm{m}}\right)$ amounted $431 \mathrm{~mm}$ and $270 \mathrm{~mm}$ in non - irrigated variant $\left(\mathrm{ET}_{\mathrm{a}}\right)$. The values of irrigation water use efficiency $\left(I_{\text {wue }}\right)$ and evapotranspiration water use efficiency $\left(E^{-} T_{\text {wue }}\right.$ ) were $1.89 \mathrm{~kg} \mathrm{~m}^{-3}$ and $1.65 \mathrm{~kg} \mathrm{~m}^{-3}$ respectively. $K_{y}$ value of 0.22 is expected value in a rainy year, exhibiting all essential characteristics of climate conditions of 2016 rainy year.

These preliminary results may be used as a good platform for basil cultivation in the Vojvodina region, in terms of advancing and improving its irrigated farming.

\section{References}

Adamović, S. (2012a). Agronomic factors affecting yield and essential oil of Ocimum basilicum L. Proceedings of the 7 th Conference on Medicinal and Aromatic Plants of Southeast European Countries, (pp. 299-392). Subotica, Republic of Serbia.

Adamović, S. (2012b). Yield and quality of basil grown as a second crop under organic and conventional conditions. XVI International EcoConference 2012, (pp. 315-319). Novi Sad, Serbia.

Biesiada, A., Kus, A. (2010). The effect of nitrogen fertilization and irrigation on yieding and nutritional status of sweet basil (Ocimum basilicum L.). Acta Scientiarum Polonorum, Hortorum Cultus, 9 (2), 3-12.

Bos, M.G. (1980). Irrigation efficiencies at crop production. ICID Bulletin, 29, 18-25.

Bos, M.G. (1985). Summary of ICID definitions of irrigation efficiency. ICID Bulletin, 34, 28-31.

Bošnjak, Dj. (2001). The problems of drought in the Vojvodina province and drought control measures. A Periodical of Scientific Research on Field and Vegetable Crops, 35, 391-401.

Çakir, R. (2004). Effect of water stress at different development stages on vegetative and reproductive growth of corn. Field Crops Research, 89, 1-6. 
Doorenbos, J., Kassam, A.H. (1979). Yield response to water. FAO Publication No.33, Rome.

Ekren, S., Sonmez, C., Ozcakal, E., Kurttas, Y.S.K., Bayram, E., Gurgulu, H. (2012). The effect of different irrigation water levels on yield and quality characteristics of purple basil (Ocimum basilicum L.). Agricultural Water Management, 109, 155-161.

Ghamarnia, H., Amirkhani, D., Arji, I. (2015). Basil (Ocimum basilicum L.) water use, crop coefficients and SIMDvalKc model implementing in a semi-arid climate. International Journal of Plant and Soil Science, 4 (6), 535-547.

Hargreaves, G.H., Samani, Z.A. (1985). Reference crop evapotranspiration from temperature. Applied Engineering in Agriculture, 1, 96-99.

Howell, A. (2001). Enhancing water use efficiency in irrigated agriculture. Agronomy Journal, 93, 281-289.

Jevđović, R., Todorović, G., Kostić, M., Pavlović, R., Jevđović, M., Dekić, S. (2009). Uticaj navodnjavanja na prinos nadzemne biomase bosiljka (Ocimum basilicum L.). Savetovanje o biotehnologiji, 14, pp. 169 -173. Čačak.

Khalid, Kh. A. (2006). Influence of water stress on growth, essential oil, and chemical composition of herbs (Ocimum sp.). International Agrophysics, 20, 289-296.

Kišgeci, J., Adamović, D. (1994). Gajenje lekovitog bilja. Beograd: Nolit.

Moeini Alishah, H., Heidari, R., Hassani, A., Asadi Dizaii, A. (2006). Effect of water stress on some morphological and biochemical characteristics of purple basil (Ocimum basilicum L.). Journal of Biological Science, 6 (4), 763-767.
Ph. Jug. V (2000). Savezni zavod za zaštitu i unapređenje zdravlja, Beograd.

Srivastava, A.K. (1980). French Basil and its Cultivation in India. Farm Bulletin No 16, Central Institute of Medicinal and Aromaic Plants, Lucknow, p 15.

Simon, J.E., Quinn, J., Murray, R.G. (1990). Basil: a source of essential oils. In J. Janick, \& J. E. Simon (Eds.), Advances in New Crops (pp. 484 -489). Portland, OR: Timber Press.

Singh., M. (2002). Effect of nitrogen and irrigation regimes on the yield an quality of sweet basil (Ocimum basilicum L.). Journal of Spices and Aromatic Crops, 11 (2), 151-154.

Payero, J.O., Melvin, S.R. Irmak, S., Tarkalson, D. (2006). Yield response of corn to deficit irrigation in a semiarid climate. Agricultural Water Management, 84, 101-112.

Pejić, B., Maksimović, L., Škorić, D., Milić, S., Stričević, R., Cupina, B. (2009). Effect of water stress on yield and evapotranspiration of sunflower. Helia, 32 (51), 19-33.

Pejić, B., Gvozdanović-Varga, J., Milić, S., Ignjatović-Ćupina, A., Krstić Di., Ćupina, B. (2011). Effect of irrigation schedules on vield and water use of onion (Allium cepa L.). African Journal of Biotechnology, 10, 2644-2652.

Pejić, B., Gajić, B., Bošnjak, Dj., Stričević, R., Mačkić, K., Kresović, B., 2014. Effects of water stress on water use and yield of onion. Bulgarian Journal of Agricultural Science, 20, 297-302.

Yassen, M., Ram, P., Anju, Y., Singh, K. (2003). Response of Indian basil (Ocimum basilicum L.) to irrigation and nitrogen schedule in Central Uttar Pradesh. Annals of. Plant Physiology, 17 (2), 177-181.

\section{Efekat navodnjavanja kapanjem na prinos, evapotranspiraciju i efikasnost korišćenja vode bosiljka (Ocimum basilicum L.)}

\section{Borivoj Pejić · Dušan Adamović · Livija Maksimović · Ksenija Mačkić}

Sažetak: Eksperimentalna istraživanja o uticaju navodnjavanja kapanjem na prinos, evapotranspiraciju i efikasnost korišćenja vode bosiljka (Ocimum basilicum L.) su obavljena na oglednom polju Instituta za ratarstvo i povrtarstvo iz Novog Sada u Odeljenju za alternativne biljne vrste u Bačkom Petrovcu. Vreme zalivanja je određivano obračunom vodnog bilansa. Dnevne vrednosti utroška vode na evapotranspiraciju biljaka $\left(E T_{d}\right)$ su obračunate korišćenjem referentne evapotranspiracije $\left(\mathrm{ET}_{\mathrm{o}}\right)$ i koeficijenata useva $(\mathrm{kc})$ čije su vrednosti za maj, jun, jul i avgust $0,5,0,6,1,1$ i 1,0. Zalivanje je obavljano kada su rezerve lakopristupačne vode u sloju zemljišta dubine $0,3 \mathrm{~m}$ bile iskorišćene. Zalivna norma je iznosila $30 \mathrm{~mm}\left(30 \mathrm{l} \mathrm{m}^{-2}\right)$, a norma navodnjavanja $140 \mathrm{~mm}$. Osetljivost bosiljka na vodni stres utvrđena je obračunom koeficijenta opadanja prinosa $\left(\mathrm{K}_{\mathrm{y}}\right)$. Prinos zelene mase navodnjavanog bosiljka $\left(32,015 \mathrm{t} \mathrm{ha} \mathrm{a}^{-1}\right)$ je bio veći za $9 \%$ u poređenju sa nenavodnjavanom, kontrolnom varijantom $\left(29,364 \mathrm{t} \mathrm{ha}^{-1}\right)$. Takođe, navodnjavanje je značajno uticalo na prinos etarskog ulja bosiljka $\left(35,329 / 28,766 \mathrm{~kg} \mathrm{ha}^{-1}\right)$. U prvom otkosu sadržaj etarskog ulja je bio značajno veći na navodnjavanoj varijanti $\left(6,45 \mathrm{~g} \mathrm{~kg}^{-1}\right)$ u poređenju sa nenavodnjavanom varijantom $\left(5,33 \mathrm{~g} \mathrm{~kg}^{-1}\right)$, dok u drugom otkosu nisu utvrđene značajne razlike između navodnjavane i kontrolne varijante $\left(6,83\right.$ and $\left.6,62 \mathrm{~g} \mathrm{~kg}^{-1}\right)$. Utrošak vode na evapotranspiraciju biljaka u uslovima navodnjavanja $\left(\mathrm{ET}_{\mathrm{m}}\right)$ iznosio je $431 \mathrm{~mm}$, a u uslovima bez navodnjavanja $\left(\mathrm{ET}_{\mathrm{a}}\right) 270 \mathrm{~mm}$. Vrednosti koeficijenata iskorišćenosti vode dodate navodnjavanjem $\left(\mathrm{ET}_{\mathrm{wue}}\right) \mathrm{i}$ vode utrošene na evapotranspiraciju biljaka iznosile su $1,89 \mathrm{~kg} \mathrm{~m}^{-3}$, odnosno $1,65 \mathrm{~kg} \mathrm{~m}^{-3}$. Vrednosti $\mathrm{K}_{\mathrm{y}}(0,22)$ su uslovljene vremenskim uslovima kišne 2016. godine. Preliminarni rezultati istraživanja mogu biti korišćeni kao dobra osnova za proizvođače bosiljka u regionu, pre svega, u smislu racionalnog korišćenja vode za navodnjavanje.

Ključne reči: bosiljak, Ocimum basilicum L., efikasnost korišćenja vode, evapotranspiracija, navodnjavanje, prinos 